\title{
Dysfunction of Tubular Phosphate Reabsorption Related to Glomerular Filtration and Blood Glucose Control in Diabetic Children
}

\author{
J. Ditzel $^{1}$, J. Brøchner-Mortensen ${ }^{2}$ and R. Kawahara ${ }^{1}$ \\ ${ }^{1}$ Section of Endocrinology and Metabolism, Department of Medicine, ${ }^{2}$ Departments of Clinical Physiology and Clinical Chemistry, \\ Aalborg Regional Hospital, Denmark
}

\begin{abstract}
Summary. The renal handling of inorganic phosphate was studied by measuring the urinary excretion rate of phosphate $\left(\mathrm{U}_{\mathrm{PO}_{4}} \mathrm{~V}\right)$, phosphate- $\left(\mathrm{Cr}^{51}\right)$ EDTA clearance ratio $\left(\mathrm{C}_{\mathrm{PO}_{4}} / \mathrm{GFR}\right)$ and maximal tubular reabsorption of phosphate per litre glomerular filtrate $\left(\mathrm{Tm}_{\mathrm{PO}_{4}} / \mathrm{GFR}\right)$ during fasting in 26 ambulatory Type 1 (insulin-dependent) diabetic children without clinical signs of microangiopathy (age: 7-14 years; duration of disease: 3-14 years). Similar measurements were made in 28 healthy schoolchildren (age: 8-14 years). $\mathrm{U}_{\mathrm{PO}_{4}} \mathrm{~V}$ and $\mathrm{C}_{\mathrm{PO}_{4}}{ }^{\prime}$ GFR were significantly enhanced in the diabetic children $(p<0.001)$ and correlated with the degree of hyperglycaemia $(p<0.005)$. $\mathrm{Tm}_{\mathrm{PO}_{4}} / \mathrm{GFR}$ was significantly suppressed in the diabetic children (1.23 versus $1.73 \mathrm{mmol} / 1, p<0.001)$. This disturbance was neither related to changes in serum parathyroid hormone nor to growth hormone concentrations but was inversely correlated with the degree of hyperglycaemia $(r=$
\end{abstract}

$-0.61, p<0.001)$ and with tubular reabsorption of glucose $(r=-0.53, p<0.01)$. In spite of the markedly lowered $\mathrm{Tm}_{\mathrm{PO}_{4}}$ ' GFR in the diabetic subjects, the mean maximal $\left(\mathrm{Tm}_{\mathrm{PO}_{4}}\right)$ and absolute tubular phosphate reabsorption rates were equal to those of the 28 healthy subjects. Both in the diabetic and healthy subjects, these parameters were positively correlated with glomerular filtration rate which was significantly elevated in the diabetic children (138 versus $109 \mathrm{ml} / \mathrm{min}$ per $1.73 \mathrm{~m}^{2}$, $p<0.01$ ). The study demonstrates a dysfunction in tubular phosphate reabsorption in diabetic children which is related to glycaemic regulation.

Key words: Type 1 diabetes, glomerular filtration rate, renal function, renal phosphate threshold concentration, plasma inorganic phosphate.
In Type 1 (insulin-dependent) diabetic patients, functional glomerular changes are known to occur from the early stages of the disease. The glomerular filtration rate (GFR) is significantly increased by $25-30 \%$ in diabetic children compared with healthy children $[1,2]$. This abnormality in GFR of juvenile diabetic subjects fluctuates and is readily reversible with optimal glucose regulation [3, 4].

Functional changes in the renal tubular system may also occur from the onset of Type 1 diabetes. Fasting urinary excretion of inorganic phosphate is increased and the maximal capacity of renal tubular reabsorption of phosphate per litre of filtrate $\left(\mathrm{Tm}_{\mathrm{PO}_{4}} / \mathrm{GFR}\right)$ is significantly decreased [5-7]. These tubular abnormalities are also reversible and probably related to blood glucose control $[8,9]$. As both glucose and phosphate transport in the proximal tubules are coupled to active sodium entry into the tubular cells, it is likely that glucose reabsorption interfers with phosphate reabsorption by inhibiting phosphate affinity at the tubular brush border membrane $[10,11]$.
Hitherto, detailed studies of the renal handling of inorganic phosphate in diabetic children have not been reported. We present here a study in which the urinary excretion rate of phosphate $\left(\mathrm{U}_{\mathrm{PO}_{4}} \mathrm{~V}\right)$, phosphate- $\left(\mathrm{Cr}^{51}\right)$ EDTA clearance ratio $\left(\mathrm{C}_{\mathrm{PO}_{4}} / \mathrm{GFR}\right)$ and $\mathrm{Tm}_{\mathrm{PO}_{4}} / \mathrm{GFR}$ were determined and compared with similar measurements in normal children.

The observations demonstrate that a dysfunction of the tubular handling of phosphate is present in subjects with Type 1 diabetes, the degree of which is related to hyperglycaemia.

\section{Patients and Methods}

Twenty-six ambulatory children with Type 1 diabetes (17 girls and 9 boys, aged 7-14 years, mean 11.8 years; duration of diabetes 3-14 years, mean 6.8 years) participated in the study. Twenty-eight healthy school children (13 girls and 15 boys, aged 8-14 years, mean 11.8 years) served as control subjects. Informed consent was obtained from parents for both normal and diabetic children. Arterialized capillary blood $\mathrm{pH}$ was normal in all (range 7.36-7.44) with mean $\mathrm{pH}$ of 7.40 in the two groups. The mean standard bicarbonate was slightly 
Table 1. Urinary excretion rates, maximal $\left(\mathrm{Tm}_{\mathrm{PO}_{4}}\right)$ and absolute reabsorption rates of phosphate and plasma concentrations in ambulatory diabetic and healthy children

\begin{tabular}{|c|c|c|c|}
\hline Parameters & $\begin{array}{l}\text { Diabetic } \\
\text { children } \\
(n=26)\end{array}$ & $\begin{array}{l}\text { Healthy } \\
\text { children } \\
(n=28)\end{array}$ & $p$ \\
\hline $\begin{array}{l}\mathrm{PO}_{4} \text { excretion rate } \\
(\mathrm{mmol} / \mathrm{h})\end{array}$ & $1.19 \pm 0.36$ & $0.43 \pm 0.22$ & $<0.001$ \\
\hline $\begin{array}{l}\mathrm{Tm}_{\mathrm{PO}_{4}} \\
\left(\mathrm{mmol} / \mathrm{h} \text { per } 1.73 \mathrm{~m}^{2}\right)\end{array}$ & $10.18 \pm 2.12$ & $11.23 \pm 1.89$ & NS \\
\hline $\begin{array}{l}\mathrm{PO}_{4} \text { reabsorption rate } \\
\left(\mathrm{mmol} / \mathrm{h} \text { per } 1.73 \mathrm{~m}^{2}\right)\end{array}$ & $10.07 \pm 1.69$ & $9.22 \pm 1.33$ & NS \\
\hline $\begin{array}{l}\text { Serum parathyroid } \\
\text { hormone }(U / 1)\end{array}$ & $2.78 \pm 0.67$ & $3.03 \pm 1.04$ & NS \\
\hline $\begin{array}{l}\text { Serum growth hormone } \\
(\mathrm{nmol} / \mathrm{l})\end{array}$ & $4.7 \pm 4.52$ & $6.6 \pm 6.79$ & NS \\
\hline Plasma $\mathrm{PO}_{4}(\mathrm{mmol} / \mathrm{l})$ & $1.36 \pm 0.13$ & $1.48 \pm 0.16$ & $<0.005$ \\
\hline $\begin{array}{l}\text { Blood glucose } \\
(\mathrm{mmol} / \mathrm{l})\end{array}$ & $13.2 \pm 4.16$ & $4.5 \pm 0.25$ & $<0.001$ \\
\hline $\begin{array}{l}\text { Urine glucose } \\
\left(\mathrm{mmol} / \mathrm{h} \text { per } 1.73 \mathrm{~m}^{2}\right)\end{array}$ & $11.0 \pm 10.87$ & - & - \\
\hline
\end{tabular}

Results expressed as mean $\pm \mathrm{SD}$; NS $=$ not significant

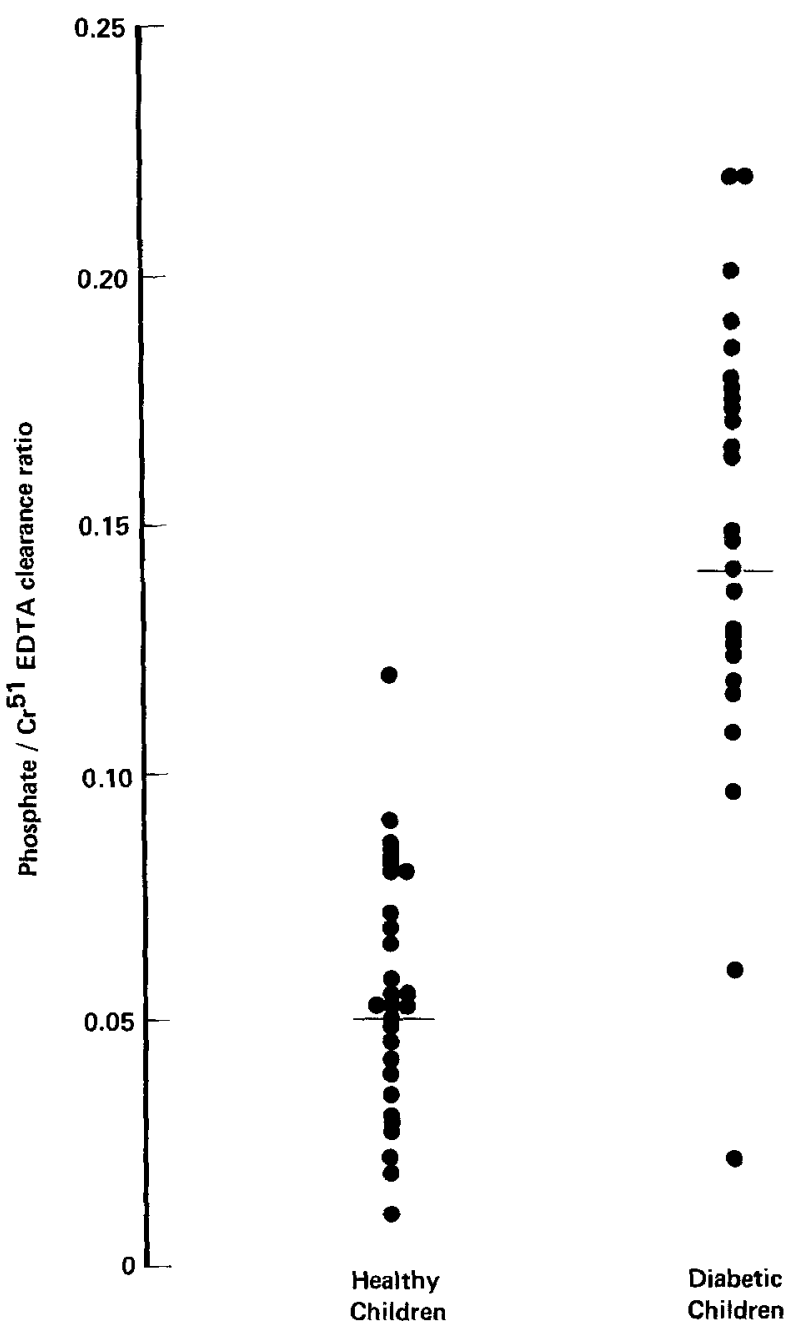

Fig. 1. Phosphate $/\left(\mathrm{Cr}^{51}\right)$ EDTA clearance ratio in the 28 healthy and 26 diabetic children. The horizontal lines indicate mean values, which were 0.057 in the healthy children and 0.146 in the diabetic children lower in the diabetic children $(22.9 \pm 1.71$ versus $23.7 \pm 0.98 \mathrm{mmol} / \mathrm{l}$, $p<0.05$ ). Serum creatinine was normal and proteinuria, tested by Albustix, was not detected in any of the children. None of the diabetic children had retinopathy. Before the study, the children had consumed a diet free of phosphorus restriction and estimations by a dietician indicated a daily phosphorus intake between $1200-2200 \mathrm{mg}$ in both groups.

All children were studied supine between 08.00 and $10.00 \mathrm{~h}$ after at least $12 \mathrm{~h}$ fasting and preceded by voiding urine. During the study period, $200 \mathrm{ml}$ water was given by mouth. The usual morning dose of insulin was deferred until the end of the test and none of the diabetic children had received insulin for at least $14 \mathrm{~h}$.

Glomerular filtration rate $\left(\mathrm{ml} / \mathrm{min}\right.$ per $\left.1.73 \mathrm{~m}^{2}\right)$ was determined from the total $\left(\mathrm{Cr}^{51}\right)$ EDTA plasma clearance, measured by a simplified single injection method [12] over $2 \mathrm{~h}$ after IV injection of $3 \mu \mathrm{Ci}\left(\mathrm{Cr}^{51}\right)$ EDTA $/ \mathrm{kg}$ body weight (maximum $100 \mu \mathrm{Ci}$ ). The minor inaccuracy of the clearance versus GFR was corrected [13]. Fasting urine was collected for $2 \mathrm{~h}$ by voluntary voiding. Free flowing blood samples were taken at the midpoint. The concentration of glucose and phosphate were determined both in urine and plasma by conventional laboratory techniques. The $\mathrm{pH}$ of arterialized capillary blood and standard bicarbonate were also measured. Serum parathyroid hormone was determined by radioimmunoassay with anti-bovine $\mathrm{C}$ terminal parathyroid antiserum (Institut National des Radioelements, Fleurus, Belgium) and serum growth hormone determinations were assayed by a double-antibody method [14] using appropriate antisera supplied by International CIS, Sorin Biomedica, Saluggia, Italy. The $\mathrm{Tm}_{\mathrm{PO}_{4}} / \mathrm{GFR}$ was derived from the corresponding plasma phosphate value and phosphate- $\left(\mathrm{Cr}^{51}\right)$ EDTA clearance ratio by using the nomogram of Walton and Bijvoet [15].

Student's t-test and Mann-Whitney's U test were used for statistical analysis.

\section{Results}

The results of the mean urinary excretion rate of phosphate $\left(\mathrm{U}_{\mathrm{PO}_{4}} \mathrm{~V}\right)$ and other relevant urine and plasma determinations in the diabetic and healthy children are shown in Table 1 . The fasting plasma inorganic phosphate concentration was significantly lower in the diabetic children $(1.36$ versus $1.48 \mathrm{mmol} / 1, p<0.005)$ and $\mathrm{U}_{\mathrm{PO}_{4}} \mathrm{~V}$ was significantly elevated in the diabetic children compared with the healthy children (1.19 versus $0.43 \mathrm{mmol} / \mathrm{h}, p<0.001)$. In the diabetic children, the phosphate excretion rate was correlated positively with the urinary excretion rate of glucose $(r=0.53, p<0.01)$ and with blood glucose $(r=0.52, p<0.01)$.

Figure 1 shows that the $\mathrm{C}_{\mathrm{PO}_{4}} /$ GFR ratio was markedly increased in the diabetic subjects compared with the healthy children $(0.146 \pm 0.046$ versus $0.057 \pm$ $0.025, p<0.001)$. In the diabetic children, the $\mathrm{C}_{\mathrm{PO}_{4}}$ / GFR ratio was correlated with blood glucose $(r=0.49$, $p<0.05$ ).

Figure 2 illustrates the individual and the mean values of the threshold concentrations for phosphate $\left(\mathrm{Tm}_{\mathrm{PO}_{4}} / \mathrm{GFR}\right)$ in the healthy and the diabetic children. The mean $\mathrm{Tm}_{\mathrm{PO}_{4}} / \mathrm{GFR}$ was $1.73 \pm 0.24 \mathrm{mmol} / 1$ in the healthy subjects compared with $1.23 \pm 0.25 \mathrm{mmol} / 1$ in the diabetic children $(p<0.001)$. Serum parathyroid hormone and human growth hormone concentrations were not significantly different in the diabetic and healthy subjects (Table 1) and the former did not correlate with $\mathrm{Tm}_{\mathrm{PO}_{4}} / \mathrm{GFR}$. From Figure 3 it is seen that the level 
of $\mathrm{Tm}_{\mathrm{PO}_{4}} / \mathrm{GFR}$ in the diabetic patients correlated inversely with the blood glucose concentration $(r=$ $-0.61, p<0.001)$. $\mathrm{Tm}_{\mathrm{PO}_{4}}$ /GFR also correlated inversely with the tubular reabsorption rate of glucose in the diabetic subjects $(r=-0.53, p<0.01)$.

Figure 4 shows that in both the diabetic and healthy subjects, the $\mathrm{Tm}_{\mathrm{PO}_{4}}$ and the renal reabsorption rates of phosphate correlated with GFR. The GFR in the diabetic children was significantly elevated compared with the healthy children $(138 \pm 13$ versus $109 \pm 13 \mathrm{ml} / \mathrm{min}$ per $\left.1.73 \mathrm{~m}^{2}, p<0.01\right)$. It is also seen from Table 1 that $\mathrm{Tm}_{\mathrm{PO}_{4}}$ and the absolute reabsorption rate of phosphate were similar to those of the control children. Thus, in spite of the markedly lowered $\mathrm{Tm}_{\mathrm{PO}_{4}} / \mathrm{GFR}$ in the diabetic children, the $\mathrm{Tm}_{\mathrm{PO}_{4}}$ and the absolute renal reabsorption rate of phosphate were not decreased compared with the healthy children.

\section{Discussion}

This study, performed in comparable groups of healthy and insulin-dependent diabetic children, confirms the presence of a dysfunction of renal handling of inorganic phosphate in diabetes [6-9]. The urinary excretion rate of phosphate and the fractional urinary excretion of phosphate (Fig. 1) were significantly increased and $\mathrm{Tm}_{\mathrm{PO}_{4}} / \mathrm{GFR}$, derived from the nomogram of Walton and Bijvoet [15], was significantly lowered in the diabetic subjects (Fig. 2). As the concentrations of parathyroid hormone and growth hormone are factors known to affect tubular phosphate reabsorption and $\mathrm{Tm}_{\mathrm{PO}_{4}} / \mathrm{GFR}$ $[16,17]$, these hormones were determined. An increased parathyroid hormone level inhibits $\mathrm{Tm}_{\mathrm{PO}_{4}} / \mathrm{GFR}$. However, in the diabetic children, the mean parathyroid hormone concentration was similar to that of the healthy children (Table 1) and parathyroid hormone level did not correlate with $\mathrm{Tm}_{\mathrm{PO}_{4}} / \mathrm{GFR}$. Decreased levels of growth hormone also lower $\mathrm{Tm}_{\mathrm{PO}_{4}} / \mathrm{GFR}$, but the concentration of growth hormone was not decreased in the diabetic children (Table 1). On the other hand, we found that the abnormalities in renal handling of phosphate were closely related to the blood glucose concen-

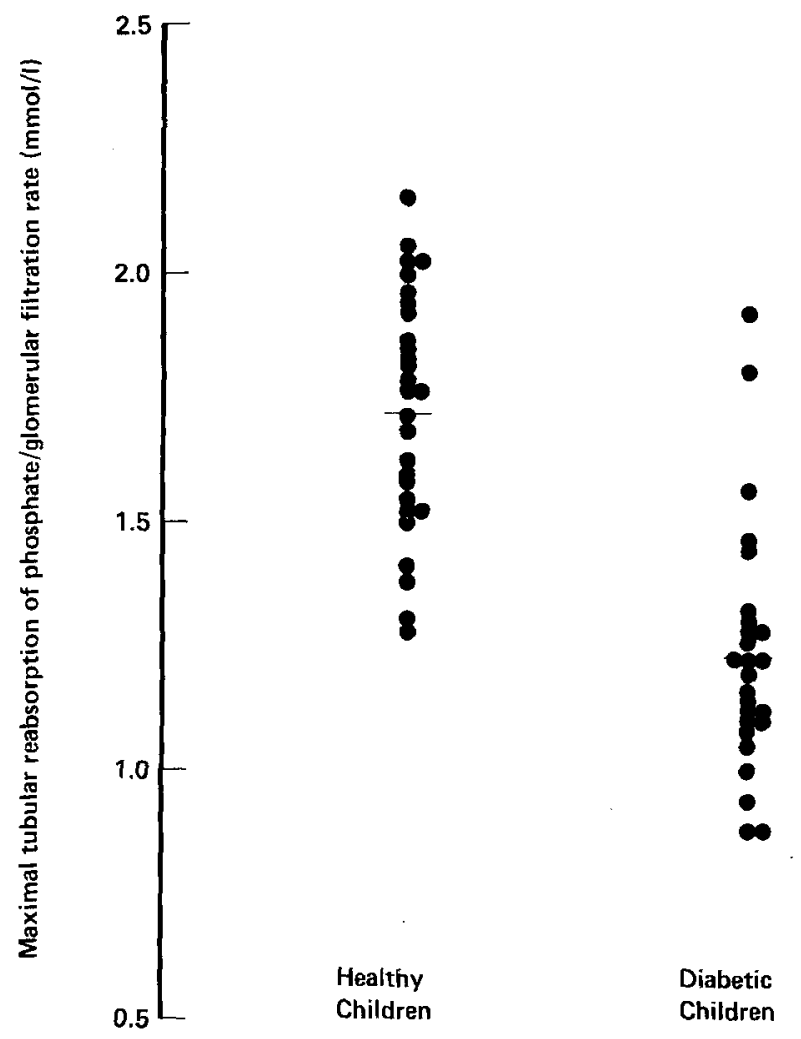

Fig. 2. The threshold concentration for phosphate in the 28 healthy and 26 diabetic children. The horizontal lines indicate mean values which were $1.73 \mathrm{mmol} / 1$ in the healthy children and $1.23 \mathrm{mmol} / 1$ in the diabetic children

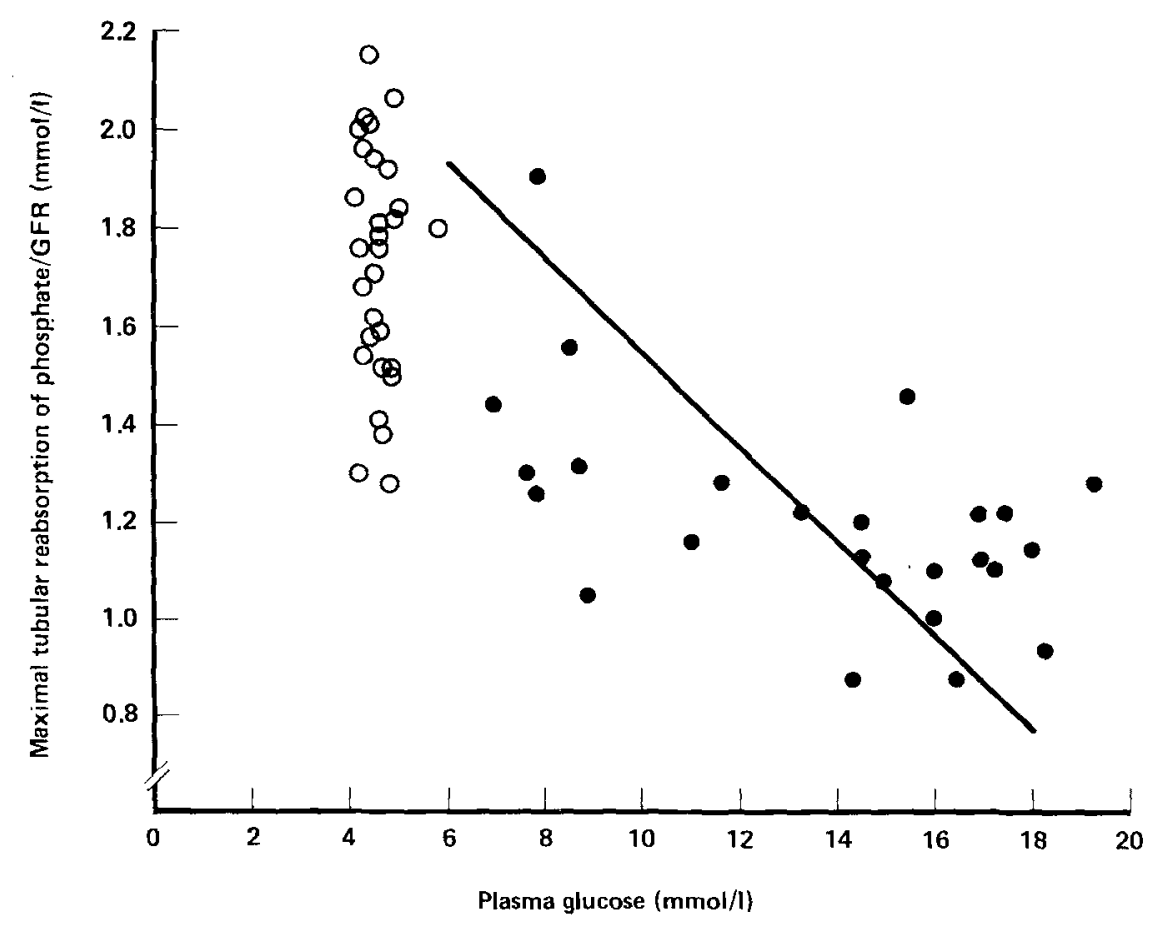

Fig. 3. Correlation between the threshold concentration for phosphate and plasma glucose. Diabetic children $(\bullet)(n=26) \mathrm{y}=-0.03 \mathrm{x}+$ $1.71 ; r=-0.61, p<0.001$ 

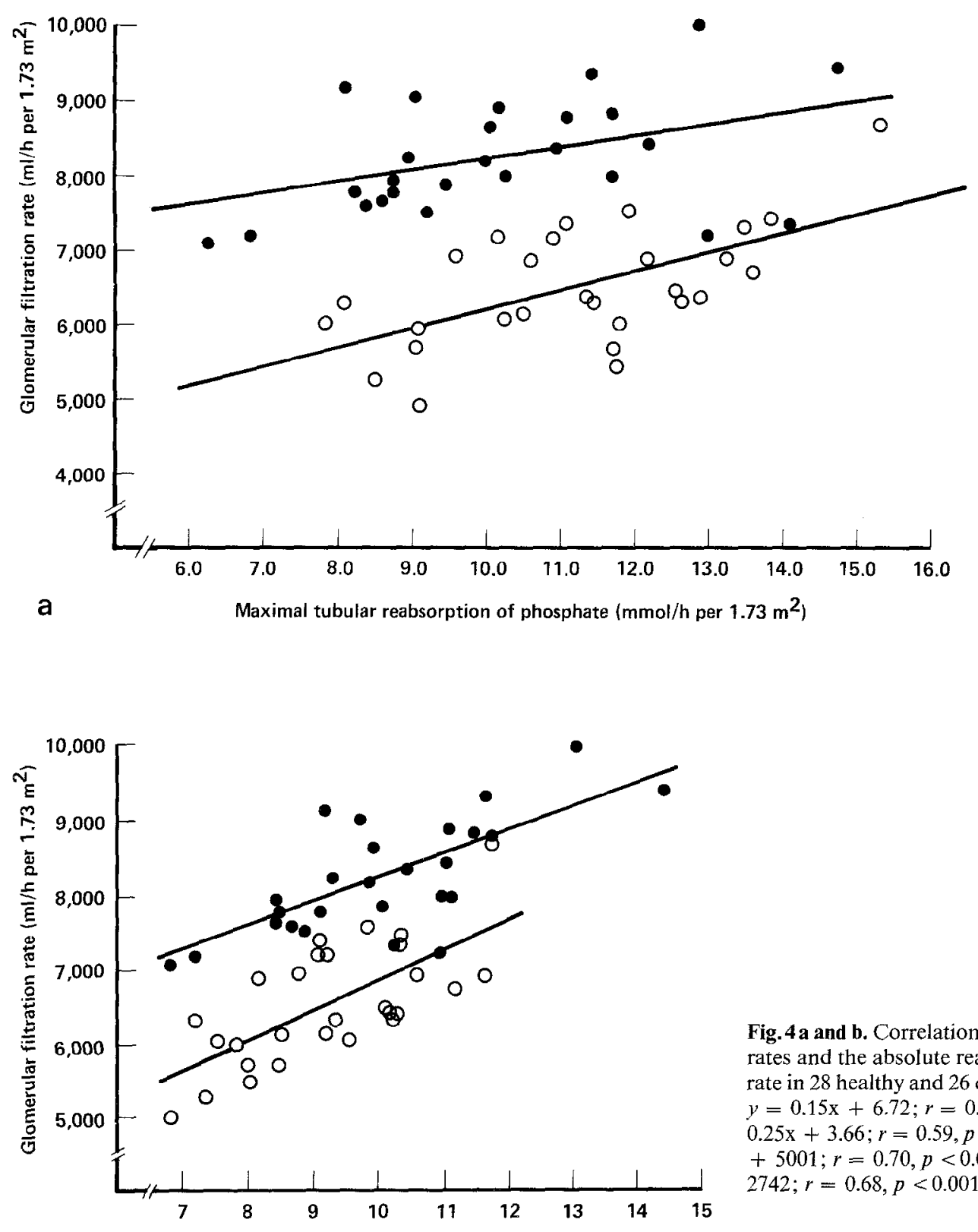

Fig. 4 a and b. Correlation of the maximal phosphate reabsorption rates and the absolute reabsorption rates to glomerular filtration rate in 28 healthy and 26 diabetic children. a Diabetic children $(\bullet)$ : $y=0.15 \mathrm{x}+6.72 ; r=0.41, p<0.05$; healthy children $(0): y=$ $0.25 \mathrm{x}+3.66 ; r=0.59, p<0.01 ; \mathbf{b}$ diabetic children $(\bullet): y=325 \mathrm{x}$ $+5001 ; r=0.70, p<0.001$; healthy children $(0): y=410 \mathrm{x}+$ $2742 ; r=0.68, p<0.001$

tration and to the rate of tubular reabsorption of glucose. The higher the fasting blood glucose, and therefore the reabsorption rate of glucose, the lower the $\mathrm{Tm}_{\mathrm{PO}_{4}} / \mathrm{GFR}$ (Fig. 3). This suppression of $\mathrm{Tm}_{\mathrm{PO}_{4}} / \mathrm{GFR}$ is reversible with the control of blood glucose. Gertner et al. [9] have elegantly demonstrated this reversibility in Type 1 diabetic patients examined before and after euglycaemia induced by insulin pump therapy. With the restoration of normoglycaemia, a striking rise occurred in $\mathrm{Tm}_{\mathrm{PO}_{4}} / \mathrm{GFR}$ and in plasma $\mathrm{PO}_{4}$ concentration. The inhibitory effect of glucose is linked to glucose reabsorption per se and not to a non-specific osmotic intraluminal effect. Experimental work has clearly shown that when mannitol is substituted for glucose, no change in phosphate reabsorption occurs $[18,19]$. In addition, this effect of glucose is not secondary to insulin action [20].
In the present study, it is of interest to note that in spite of the considerable lowering of $\mathrm{Tm}_{\mathrm{PO}} / \mathrm{GFR}$, the difference between the plasma $\mathrm{PO}_{4}$ in the diabetic and healthy children was negligible. This would indicate that a compensatory change occurs in the diabetic children, leading to a normalization of the absolute tubular reabsorption rate of phosphate. In the diabetic children, the absolute phosphate reabsorption rate was correlated with GFR (Fig.4) and the GFR was significantly elevated to such an extent that the absolute phosphate reabsorption in the diabetic children became equivalent to that of the healthy children.

According to the classical theory formulated by Homer Smith [21] which is accepted by most investigators, the rate of proximal reabsorption is automatically adjusted by changes in GFR, thereby preserving glomerulo-tubular balance. Previously Mogensen [22] has 
shown in patients with Type 1 diabetes of short duration that the maximal tubular reabsorption capacity for glucose is elevated to approximately the same degree as GFR. Thus, the glomerulo-tubular balance for glucose is maintained in these patients. From the present study it is evident that $\mathrm{Tm}_{\mathrm{PO}_{4}}$ was not elevated in the diabetic children in spite of their significantly increased GFR. Therefore, the glumerulo-tubular balance for phosphate is not maintained in these patients.

An alternative hypothesis, "the distal tubular feedback hypothesis', for the relationship between GFR and tubular function postulates that the proximal reabsorption capacity is the primary variable and that significant changes in GFR are secondary to alterations, predominently in proximal tubular reabsorption rate [23, 24]. It should be remembered that both glucose and inorganic phosphate reabsorption in the proximal tubules are sodium-dependent and are transported competitively [10]. This suggests the possibility that increased glucose reabsorption leads to obligatory sodium reabsorption, thereby normalizing the absolute phosphate reabsorption rate of the diabetic children (co-transport). As the tubular sodium load is normally almost totally reabsorbed (> 99\%), a significant increase in coupled sodium - (solute-linked isotonic water) reabsorption has to be mediated by an increase in GFR. If this interpretation of our data is correct, it may explain why both the lowered $\mathrm{Tm}_{\mathrm{PO}_{4}} / \mathrm{GFR}$ and the increased GFR are readily reversible with optimal regulation of blood glucose.

In conclusion, this study demonstrates a dysfunction of tubular handling of inorganic phosphate in diabetic children which is probably secondary to the abnormality of glucose metabolism.

Acknowledgment. This work was supported by the City of Aalborg Medical Fund. We are grateful for the expert technical assistance of E. Ditzel, H.Jensen, H. Foltved and G.Dahl Hansen. We thank Dr. N.Fogh-Andersen for the determinations of serum parathyroid hormone and Dr. P. Leyssac, University Institute for Experimental Medicine, Copenhagen, for stimulating discussions.

\section{References}

1. Stalder, G, Schmid R, Wolff M (1960) Funktionelle Mikroangiopathie der Nieren beim behandelten Diabetes mellitus im Kindesalter. Dtsch Med Wochenschr 85: 346-350

2. Brøchner-Mortensen J, Ditzel J, Mogensen CE, Rødbro P (1979) Microvascular permeability to albumin and glomerular filtration rate in diabetic and normal children. Diabetologia 16:307-311

3. Mogensen CE (1971) Kidney function and glomerular permeability to macromolecules in early juvenile diabetes. Scand J Clin Lab Invest 28: 79-90

4. Ditzel J, Junker K (1972) Abnormal glomerular filtration rate, renal plasma flow and renal protein excretion in recent and shortterm diabetics. Br Med J 2: 13-19

5. Astrug AK (1966) Studies on the clearance and tubular reabsorption of phosphates in diabetes and some of its complications. Diabetologia 2: 198-201

6. Ditzel J, Brøchner-Mortensen J, Hansted C, Rødbro P (1978) Changes in the renal handling of phosphate in juvenile diabetes. Acta Endocrinol [Suppl] (Copenh) 88: 24 (Abstract)
7. Raskin P, Pak CYC (1981) The effect of chronic insulin therapy on phosphate metabolism in diabetes mellitus. Diabetologia 21: $50-53$

8. Ditzel J, Brøchner-Mortensen J, Kjaergaard JJ, Rødbro P (1979) Clearance and tubular reabsorption of phosphates in insulin-dependent diabetics. Excerpta Medica. Int Congress Ser 481: 54 (Abstract)

9. Gertner JM, Tamborlane WV, Horst RL, Sherwin RS, Felig P, Genel M (1980) Mineral metabolism in diabetes mellitus: changes accompanying treatment with a portable subcutaneous insulin infusion system. J Clin Endocrinol Metab 50: 862-866

10. Knox FG, Hoppe A, Kempson SA, Shah SV, Dousa JP (1980) Cellular mechanisms of phosphate transport. In: Massry SC, Fleisch $\mathrm{H}$ (eds) Renal handling of phosphate. Plenum, New York, pp 79-114

11. Lang F (1980) Renal handling of calcium and phosphate. Klin Wochenschr 58: 985-1003

12. Brøchner-Mortensen J, Haahr J, Christoffersen J (1974) A simple method for accurate assessment of glomerular filtration rate in children. Scand J Clin Lab Invest 33:139-143

13. Brøchner-Mortensen J, Rohbrandt K, Lauritzen RB (1977) Precision of single injection $\left(\mathrm{Cr}^{51}\right)$ EDTA plasma clearance and endogenous creatinine clearance determinations in children. Scand $\mathbf{J}$ Clin Lab Invest 37: 625-629

14. Morgan CR (1966) Human growth hormone immunoassay - two antibody method using ${ }^{125}$ I-tracer. Proc Soc Exp Biol Med 121: $61-63$

15. Walton RJ, Bijvoet OLM (1975) Normogram for derivation of renal threshold phosphate concentration. Lancet II: 309-310

16. Lau K, Goldfart S, Goldberg M (1980) The effect of parathyroid hormone on renal phosphate handling. In: Massry SG, Fleisch H (eds) Renal handling of phosphate. Plenum, New York, pp 115-136

17. Ritz E, Kreusser W, Bommer J (1980) Effects of hormones other than parathyroid hormone on renal handling of phosphate. In: Massry SG, Fleisch $\mathrm{H}$ (eds) Renal handling of phosphate. Plenum, New York, pp 137-197

18. Fox M, Thur S, Rosenberg L, Segal S (1964) Impaired renal tubular function induced by sugar infusion in man. J Clin Endocrinol Metab 24: 1318-1327

19. Corman BC, Touvay C, Poujeol P, de Rouffinac C (1978) Glucose-mediated inhibition of phosphate reabsorption in rat kidney. Am J Physiol 235: F 430-439

20. De Fronzo RA, Goldberg M, Agus ZS (1976) The effects of glucose and insulin on renal electrolyte transport. J Clin Invest 58 : 83-90

21. Smith HW (1951) The kidney: structure and function in health and disease. Oxford University Press, New York

22. Mogensen CE (1971) Maximum tubular reabsorption capacity for glucose and renal hemodynamics during rapid hypertonic glucose infusion in normal and diabetic subjects. Scand J Clin Lab Invest 28: 101-109

23. Leyssac PP (1976) The renin angiotensin system and kidney function. A review of contributions to a new theory. Acta Physiol Scand Suppl 442: 1-52

24. Navar LG, Ploth DW, Bell PD (1980) Distal tubular feedback control of renal hemodynamics and autoregulation. Ann Rev Physiol 42: 557-571

Received: 29 June 1981

and in revised form: 5 July 1982

Jørn Ditzel, M. D., Ph. D.

Section of Endocrinology and Metabolism

Department of Medicine

Aalborg Regional Hospital

DK-9000 Aalborg, Denmark 